\title{
Survival rate and restricted growth of marbled crab (Pachygrapsus marmoratus) in different salinity levels
}

\section{Mermer yengecinin (Pachygrapsus marmoratus) farklı tuzluluk seviyelerinde yaşama oranı ve sınırlı büyümesi}

\author{
Onur Karadal ${ }^{1}$ \\ 'Department of Aquaculture, Faculty of Fisheries, İzmir Kâtip Çelebi University, 35620, Ç̌̆gli, İzmir, Turkey iD https://orcid.org/0000-0002-6241-5039
} onur.karadal@ikc.edu.tr

Received date: 28.05 .2018

Accepted date: 06.09.2018

\section{How to cite this paper:}

Karadal, O. (2018). Survival rate and restricted growth of marbled crab (Pachygrapsus marmoratus) in different salinity levels. Ege Journal of Fisheries and Aquatic Sciences, 35(4), 407-416. DOI:10.12714/egejfas.2018.35.4.06

\begin{abstract}
The semi-terrestrial marbled crab (Pachygrapsus marmoratus Fabricius, 1787) is one of the most common species in the intertidal belt of rocky shores of the Mediterranean Sea. This study aimed to understand survival and restricted growth of marbled crab in different salinity levels $(0,5,15,25,35 \%)$ and dry area (D). Crabs were collected from rocky shores by hand in İzmir in January 2018. Specimens (initial mean weights of $0.82 \pm 0.01 \mathrm{~g}$ and $n=180$ ) were randomly distributed to 10 -L aquariums with three replicates and they were not fed during the experiment. Results indicated that the survival times of crabs showed significant differences in salinity levels $(\mathrm{P}<0.001)$. All the individuals in the dry area and $0 \%$ salinity level died within the first 2 months. For the other salinity levels, all specific growth rate values decreased at minus on $84^{\text {th }}$ day. Forty percent of crabs in aquariums that represented $15 \%$ o salinity level were survived until the $126^{\text {th }}$ day and the experiment was ended in the $140^{\text {th }}$ day when the mortality of the last crab $(0.73 \mathrm{~g})$ occurred. In conclusion, the optimal salinity level for the survival and restricted growth of $P$. marmoratus was determined as $15 \%$ and $25 \%$, respectively. Future surveys would need to investigate the effects of different food types on survival and growth of this potential ornamental crab species of marine aquariums.
\end{abstract}

Keywords: Pachygrapsus marmoratus, salinity, survival rate, starvation, aquarium

Öz: Yarı karasal bir tür olan mermer yengeci (Pachygrapsus marmoratus Fabricius, 1787), Akdeniz'in kayalık kıyılarında bulunan gelgit zonundaki en yaygın türlerden biridir. Bu çalışma, mermer yengecinin farklı tuzluluk seviyelerinde $(\% 00,5,15,25,35)$ ve kuru ortamda (K) hayatta kalmasının ve sınırlı büyümesinin anlaşılmasını amaçlamıştır. Yengeçler, Ocak 2018'de İzmir'deki kayalık kıyılardan el ile toplanmıştır. Bireyler (ilk ortalama ağırlık $0.82 \pm 0.01 \mathrm{~g}$ ve $n=180$ ), üç replikat olmak üzere 10 -L akvaryumlara rastgele dağıtılmış ve deney sırasında beslenmemişlerdir. Bulgular, yengeçlerin hayatta kalma sürelerinin tuzluluk seviyelerine göre anlamlı farklılık gösterdiğini belirtmiştir $(\mathrm{P}<0,001)$. Kuru ortamda ve \%o 0 tuzluluk seviyesindeki tüm bireyler ilk 2 ay içinde ölmüştür. Diğer tuzluluk seviyeleri için, tüm spesifik büyüme oranları, 84. günde eksiye düşmüștür. Akvaryumlarda \%o15 tuzluluk seviyesindeki yengeçlerin yüzde kırkı 126. güne kadar hayatta kalmıs olup, çalıșma son yengeç $(0,73$ g) ölümünün meydana geldiği 140. günde sona ermiştir. Sonuç olarak, P. marmoratus'un hayatta kalma ve kısıtlı büyümesi için optimal tuzluluk düzeyi sırasıyla \%o15 ve \%o25 olarak belirlenmiştir. Gelecek çalışmalar, deniz akvaryumlarının bu potansiyel süs yengecinde hayatta kalma ve büyüme üzerine farklı besin türlerinin etkilerini araştırmalıdır.

Anahtar kelimeler: Pachygrapsus marmoratus, salinite, hayatta kalma oranı, açlık, akvaryum 


\section{INTRODUCTION}

With the development of the aquarium systems, the aquarists have interested in marine aquariums. The first marine aquarium was established in 1846 with only coral and seaweed species (Kisling, 2000). Personal saltwater aquariums have spread in the early 1950's (Vitko, 2004). Currently, 10\% of pet ownership in the U.S. have freshwater and $2 \%$ of have saltwater aquariums (APPA, 2018). About 1500 fish species have used in marine aquariums and 20-24 million fish have sold per year during the last decade (Türkmen et al., 2011). Besides the fish, invertebrate species such as shrimps and crabs have become more popular in marine aquariums (Calado et al., 2003a). The most commonly traded decapod species in the marine aquarium sector were remarked as Caridean shrimps. Brachyuran and Anomuran crabs were following this group (Penha-Lopes et al., 2005). It has been reported that four crab species belonging to Gecarcinidae and Sesarmidae families were sold in the aquarium sector in Turkey (Türkmen and Karadal, 2012a). Karadal and Öndes (2018) suggested that 35 crab species were found in the costs of Turkey, which may be considered as suitable decapods in marine aquariums.

The larval development of some crab species such as Pachygrapsus marmoratus, Mithraculus forceps, Uca tangeri, Pisa tetraodon (Rodríguez and Jones, 1993; Rodríguez, 1997; Cuesta and Rodríguez, 2000; PenhaLopes et al., 2005) were investigated in the laboratory. Calado et al. (2003b; 2007; 2008) also studied the culture and rearing system designs of marine ornamental crabs. Effects of some physical parameters (temperature, light intensity, dissolved oxygen) on crab species were reported in previous studies (Gardner and Maguire, 1998; Hamasaki, 2003; Paschke et al., 2010) in the controlled conditions. In addition, feeding characteristics and starvation were examined on some freshwater and marine crabs, including Eriocheir sinensis (Wen et al., 2006), Perisesarma bidens (Türkmen and Karadal, 2012b), M. forceps (Penha-Lopes et al., 2006; Figueiredo et al., 2008), Scylla serrata (Suprayudi et al., 2002; Ruscoe et al., 2004), and Portunus pelagicus (Redzuari et al., 2012).

Many studies indicated that some biological and ecological characteristics of crabs such as, survival (Romano and Zeng, 2006; Nurdiani and Zeng, 2007), geographical distribution (Bryars and Havenhand, 2006), gonadal development (Fisher, 1999; Long et al., 2017), growth (Castejón et al., 2015), oxygen consumption (Winch and Hodgson, 2007), feeding behaviour (Shentu et al., 2015), and limb regeneration (Stueckle et al., 2009) were influenced by salinity. In addition to the impacts of salinity, some studies noticed that the combined effects of salinity and temperature on the development of crab species (Blaszkowski and Moreira, 1986; Paula et al., 2003).
Pachygrapsus marmoratus, commonly known as the marbled rock crab or marbled crab, which is one of the most common grapsid species in the intertidal belt of rocky shores throughout the Mediterranean Sea, Black Sea and North-eastern Atlantic coasts of Southern Europe (Flores and Paula, 2002a; Dauvin, 2012; Vinagre et al., 2012; Deli et al., 2015). This semi-terrestrial crab cannot be considered an opportunistic feeder and its diet mainly consists of limpets, barnacles, mussels, and algae (Cannicci et al., 2002; Silva et al., 2009).

Previous studies on marbled crab were related to the distribution and population structure (Cannicci et al., 1999; Flores and Paula, 2002a; Silva et al., 2009; Aydın et al., 2014; Arab et al., 2015; Sumer et al., 2016), relative growth (Protopapas et al., 2007), feeding habits (Cannicci et al., 2002; Cannicci et al., 2007; Silva et al., 2009) and reproductive ecology (Flores and Paula, 2002b). However, this species has been little investigated in the tank or aquarium to date (Sciberras and Schembri, 2008; Madeira et al., 2012; Coquereau et al., 2016). There has been no comprehensive study on the survival rates without food and salinity tolerances of this crab species. The first objective of the present study was to compare the survival times of marbled crabs in different salinity levels without feeding in the aquarium. The second objective was to determine the restricted growth rate of marbled crabs at the aquarium conditions.

\section{MATERIAL AND METHODS}

\section{Collection of crabs and experimental conditions}

Marbled crabs (Pachygrapsus marmoratus) were collected from rocky shores by hand in Urla, İzmir $\left(38^{\circ} 22^{\prime} 17^{\prime \prime} \mathrm{N}, 26^{\circ} 45^{\prime} 44^{\prime \prime} \mathrm{E}\right)$ in January 2018. Crabs, which had same moult stage (hard carapace) and did not have limb loss, were selected for the experiment. A total of 180 crabs were transferred to aquariums in the Education \& Research Unit of Faculty of Fisheries, İmir Kâtip Çelebi University, Turkey. The experiment was performed in $10 \mathrm{~L}$ plastic aquariums filled with $6 \mathrm{~L}$ of marine water with different salinity levels. Ten crabs (initial mean weights of $0.82 \pm 0.01 \mathrm{~g}$ ) were randomly placed per each aquarium with three replicates (Figure 1). Five different salinity levels $(0,5,15,25,35 \%$ ) and dry area (D) were compared to assess information on survival times and restricted growth. Each aquarium contained 4-cm-diameter PVC pipes as the refuge and a stone, which was placed in the center of the aquarium. The water temperature of aquariums was maintained as $17.6 \pm 0.4^{\circ} \mathrm{C}$ (same temperature value of the sampling area). Salinity, temperature, dissolved oxygen and $\mathrm{pH}$ (Hach HQ40D Portable Multi Meter) were checked in each aquarium daily. Dissolved oxygen was 9.53 \pm 0.01 ppm, pH was $8.28 \pm 0.02$ and photoperiod was held at 12:12 (light/dark). The water in all aquariums was changed once a week with the ratio of $20 \%$. 


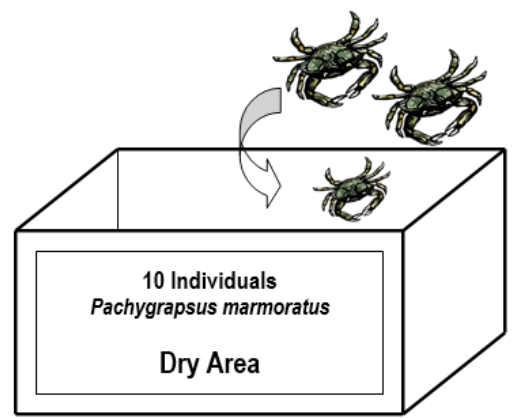

3 Replicates

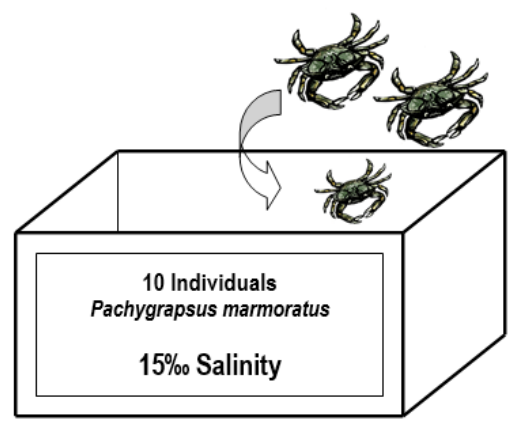

3 Replicates

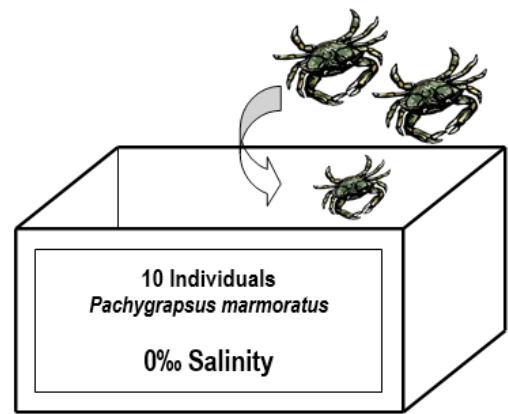

3 Replicates

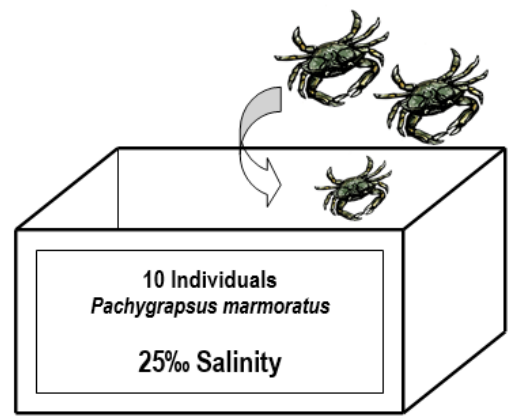

3 Replicates

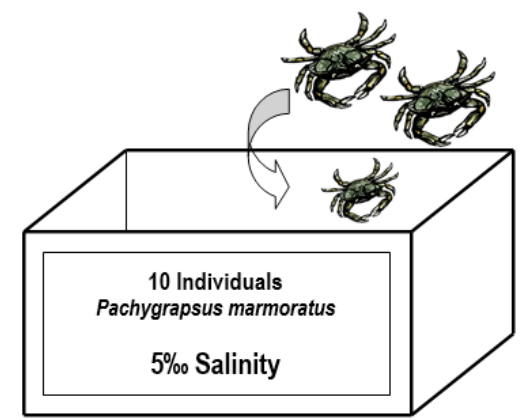

3 Replicates

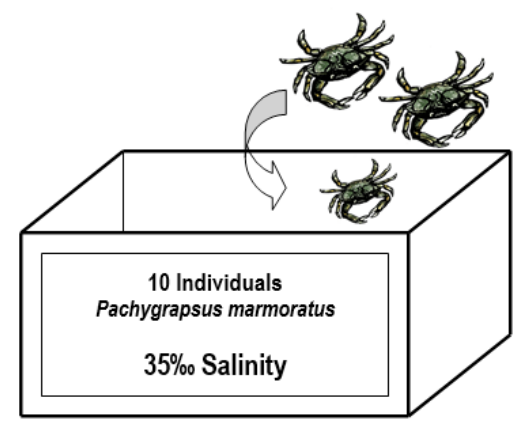

3 Replicates

Figure 1. Design of the experimental study

\section{Evaluation of restricted growth and survival rate}

Weight and length measurements were carried out biweekly during 140-days experiment. All animals were dried with a paper towel to remove water before measurement process. Crab weights were individually recorded with an electronic compact scale (SF-400D, precision of $\pm 0.01 \mathrm{~g})$. Carapace length $(\mathrm{CL}$; length of the carapace along the midline) and carapace width (CW; width of the frontal region of the carapace) were measured with the vernier caliper. All aquariums were checked daily and molting, weight, carapace length and carapace width of dead crabs were noted. The specific growth rate (SGR) was calculated as following equation: SGR $=100 \times$ [( $L n$ final crab weight $)$ - ( $L n$ initial crab weight)] / experimental days.

\section{Data analysis}

All data sets were examined to verify normality, independence, and homogeneity of variance. All data were subjected to one-way analysis of variance (ANOVA) when the interaction between the factors is found differences, Duncan's multiple range test was used to rank groups using SPSS 20.0 (SPSS Inc., Chicago, Illinois, USA) software (Zar, 1999). All data were presented as the "mean \pm standard error" from all replicates.

\section{RESULTS}

The lowest survival rates of crabs were observed in the aquariums without water (Figure 2). The survival rate of crabs with $0 \%$ o salinity level was lower than other salinity levels (5\%, $15 \%$, 25\%o, and 35\%o). Fifty percent of crabs in aquariums at the salinity levels of $15 \%$ and $25 \%$ o were survived more than 100 days (Figure 2 ). 


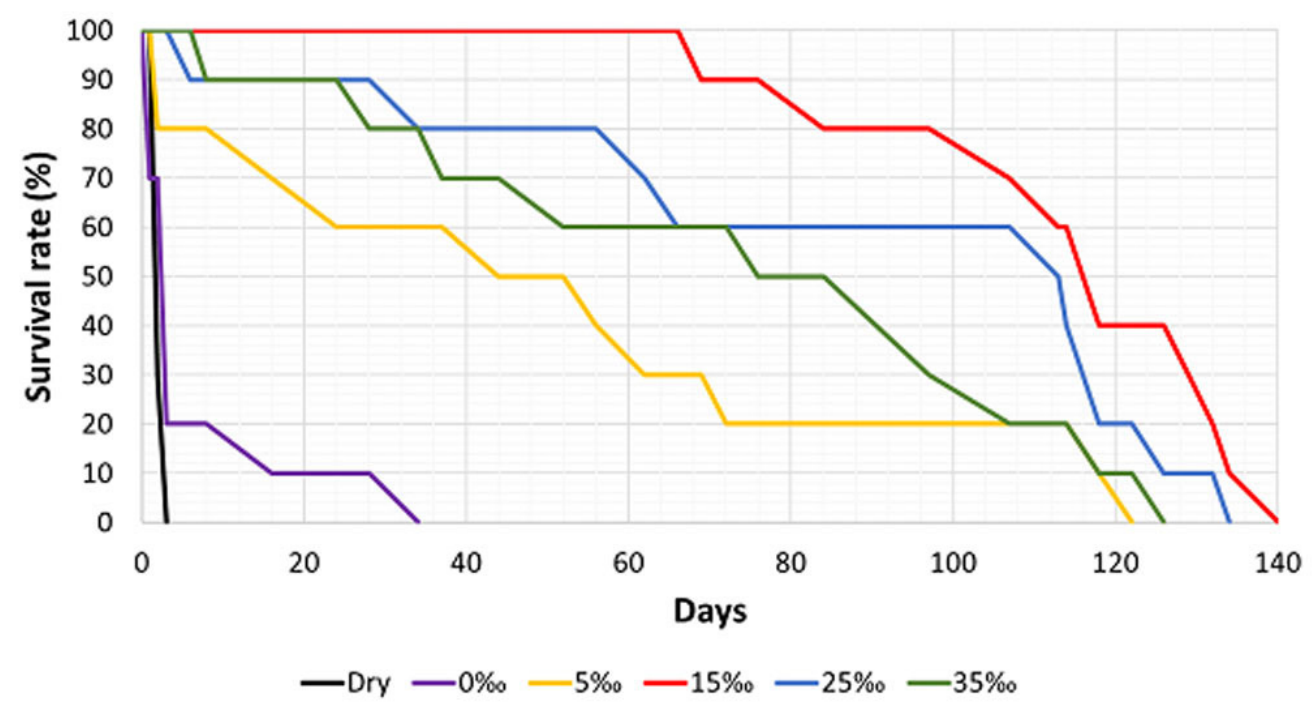

Figure 2. Survival rates (\%) of marbled crabs during 140 days period in different salinity levels

The marbled crabs survived $2.0 \pm 0.5$ days at $17.6^{\circ} \mathrm{C}$ levels exhibited longer survival times than the salinity without water and food. Our results indicated that the level of $0 \%$ o (Figure 3). The survival times of crabs highest survival time was determined as 140 days at showed significant differences in salinity levels (ANOVA, $15 \%$ salinity. Moreover, $25 \%$, $35 \%$ and $5 \%$ salinity $P<0.001, F=20.061$ ).

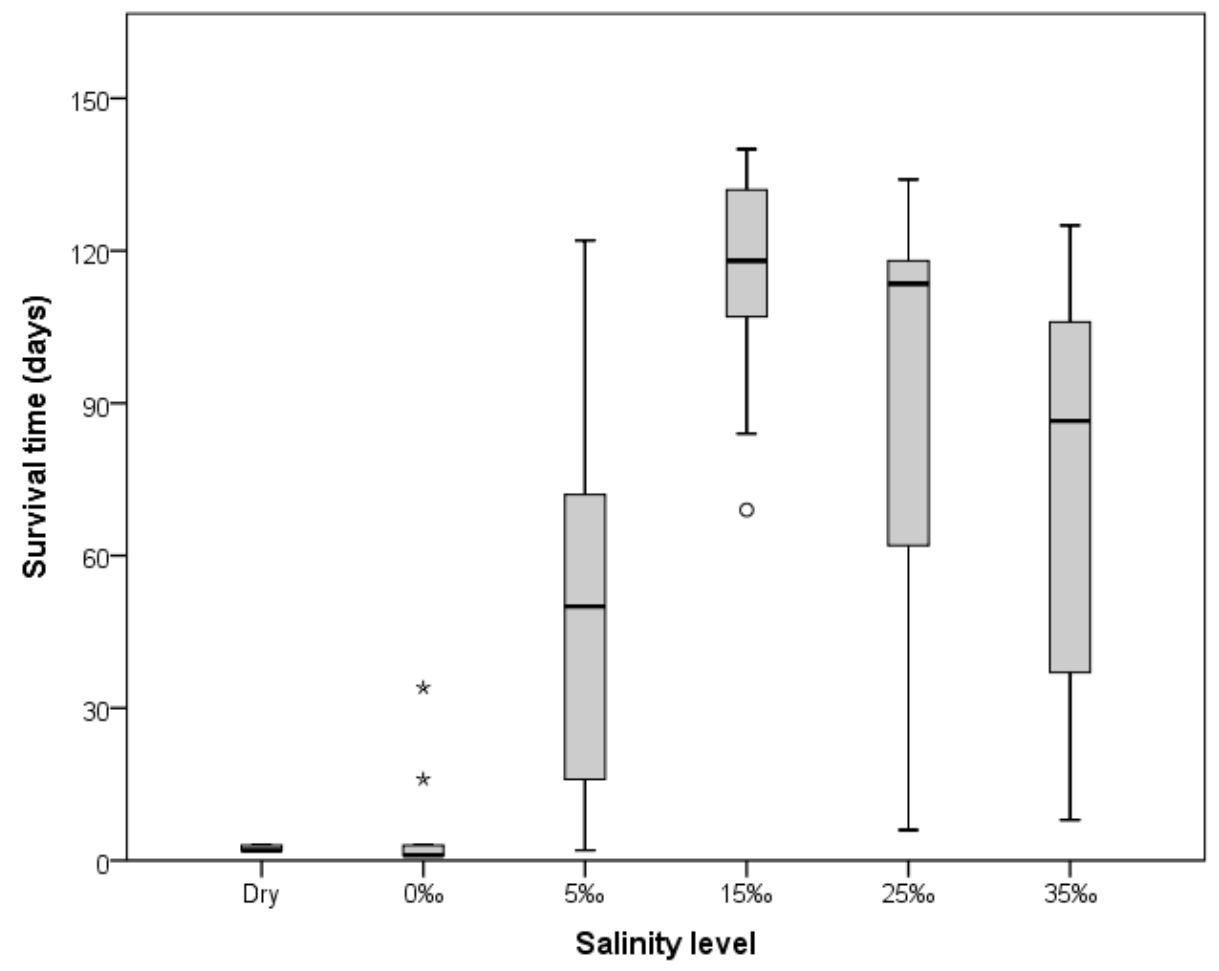

Figure 3. Survival time (days) of marbled crabs in different salinity levels 
Weight and growth changes of marbled crabs in different salinities during 140-days of the experiment were detailed in Table 1. The continuous data were not presented in D, 0\%, 5\%, $25 \%$ o and $35 \%$ groups because the mortalities were observed throughout the trial. On the $14^{\text {th }}$ day, mean weights (MW) and specific growth rates (SGR) of $25 \%$ o were significantly different from $5 \%$ o $(\mathrm{P}<0.05)$. MW of $25 \%$ o was different from $5 \%$ and the lowest SGR was found in 5\%o group on the $28^{\text {th }}$ day $(P<0.05)$. The highest and the lowest MW were observed in $25 \%$ and $5 \%$ groups, respectively $(P<0.05)$ and no statistical differences was found in SGR on $42^{\text {nd }}$ and $56^{\text {th }}$ days $(P>0.05)$. The first minus growth rate was observed in $5 \%$ group on the $56^{\text {th }}$ day. MW of $25 \%$ o was different from $5 \%$ o $(P<0.05)$ and SGR of $25 \%$ o and $35 \%$ groups were decreased to minus on the $70^{\text {th }}$ day. All SGR values were seen at minus and MW of $25 \%$ was different from $5 \%$ on the $84^{\text {th }}$ day $(\mathrm{P}<0.05)$. MWs of $15 \%$ and $25 \%$ o were significantly different from $5 \%$ o $(P<0.05)$ and no differences was observed in SGR $(\mathrm{P}>0.05)$ on the $98^{\text {th }}$ day. Only three groups $(5 \%$ o, $15 \%$ o and $25 \%$ ) survived on $112^{\text {nd }}$ day and MW of $25 \%$ was different from $5 \%$ o $(P<0.05)$. Four individuals of $15 \%$ o lived until $126^{\text {th }}$ day and last individual $(0.73 \mathrm{~g})$ died on the $140^{\text {th }}$ day.

Table 1. Mean weights (MW, g) and specific growth rates (SGR, \%/day) of the starved marbled crabs in different salinity levels during 140-days

\begin{tabular}{|c|c|c|c|c|c|c|c|}
\hline Days & & D & $0 \%$ & $5 \%$ & $15 \%$ & $25 \%$ & $35 \%$ \\
\hline 0 & MW & $0.82 \pm 0.01$ & $0.82 \pm 0.01$ & $0.81 \pm 0.01$ & $0.82 \pm 0.01$ & $0.82 \pm 0.02$ & $0.81 \pm 0.01$ \\
\hline 14 & $\begin{array}{l}\text { MW } \\
\text { SGR }\end{array}$ & & & $\begin{array}{c}0.81 \pm 0.01^{\mathrm{a}} \\
-0.03 \pm 0.09^{\mathrm{a}}\end{array}$ & $\begin{array}{l}0.84 \pm 0.01^{\mathrm{ab}} \\
0.21 \pm 0.12^{\mathrm{ab}}\end{array}$ & $\begin{array}{l}0.88 \pm 0.02^{b} \\
0.50 \pm 0.05^{b}\end{array}$ & $\begin{array}{l}0.84 \pm 0.01^{\mathrm{ab}} \\
0.23 \pm 0.10^{\mathrm{ab}}\end{array}$ \\
\hline 28 & $\begin{array}{l}\text { MW } \\
\text { SGR }\end{array}$ & & & $\begin{array}{c}0.80 \pm 0.01^{\mathrm{a}} \\
-0.09 \pm 0.03^{\mathrm{a}}\end{array}$ & $\begin{array}{l}0.86 \pm 0.01^{\mathrm{ab}} \\
0.11 \pm 0.01^{\mathrm{b}}\end{array}$ & $\begin{array}{l}0.91 \pm 0.03^{b} \\
0.23 \pm 0.04^{b}\end{array}$ & $\begin{array}{l}0.86 \pm 0.01^{\mathrm{ab}} \\
0.18 \pm 0.02^{\mathrm{b}}\end{array}$ \\
\hline 42 & $\begin{array}{l}\text { MW } \\
\text { SGR }\end{array}$ & & & $\begin{array}{l}0.81 \pm 0.01^{a} \\
0.06 \pm 0.09\end{array}$ & $\begin{array}{l}0.87 \pm 0.01^{b} \\
0.12 \pm 0.02\end{array}$ & $\begin{array}{l}0.93 \pm 0.02^{c} \\
0.22 \pm 0.11\end{array}$ & $\begin{array}{l}0.88 \pm 0.01^{b} \\
0.12 \pm 0.01\end{array}$ \\
\hline 56 & $\begin{array}{l}\text { MW } \\
\text { SGR }\end{array}$ & & & $\begin{array}{l}0.79 \pm 0.02^{\mathrm{a}} \\
-0.14 \pm 0.09\end{array}$ & $\begin{array}{l}0.87 \pm 0.01^{b} \\
0.02 \pm 0.00\end{array}$ & $\begin{array}{l}0.94 \pm 0.02^{c} \\
0.03 \pm 0.01\end{array}$ & $\begin{array}{l}0.88 \pm 0.01^{b} \\
0.04 \pm 0.01\end{array}$ \\
\hline 70 & $\begin{array}{l}\text { MW } \\
\text { SGR }\end{array}$ & & & $\begin{array}{l}0.72 \pm 0.09^{a} \\
-0.76 \pm 0.72\end{array}$ & $\begin{array}{c}0.88 \pm 0.01^{\mathrm{ab}} \\
0.04 \pm 0.03\end{array}$ & $\begin{array}{l}0.91 \pm 0.01^{b} \\
-0.21 \pm 0.10\end{array}$ & $\begin{array}{l}0.87 \pm 0.01^{\mathrm{ab}} \\
-0.07 \pm 0.02\end{array}$ \\
\hline 84 & $\begin{array}{l}\text { MW } \\
\text { SGR }\end{array}$ & & & $\begin{array}{l}0.69 \pm 0.09^{a} \\
-0.26 \pm 0.08\end{array}$ & $\begin{array}{c}0.85 \pm 0.01^{\mathrm{ab}} \\
-0.23 \pm 0.04\end{array}$ & $\begin{array}{l}0.90 \pm 0.01^{b} \\
-0.07 \pm 0.04\end{array}$ & $\begin{array}{c}0.87 \pm 0.01^{\mathrm{ab}} \\
-0.07 \pm 0.01\end{array}$ \\
\hline 98 & $\begin{array}{l}\text { MW } \\
\text { SGR }\end{array}$ & & & $\begin{array}{l}0.68 \pm 0.07^{a} \\
-0.08 \pm 0.20\end{array}$ & $\begin{array}{l}0.83 \pm 0.01^{b} \\
-0.14 \pm 0.02\end{array}$ & $\begin{array}{l}0.90 \pm 0.02^{b} \\
-0.01 \pm 0.20\end{array}$ & $\begin{array}{l}0.83 \pm 0.01^{\mathrm{ab}} \\
-0.34 \pm 0.01\end{array}$ \\
\hline 112 & $\begin{array}{l}\text { MW } \\
\text { SGR }\end{array}$ & & & $\begin{array}{l}0.68 \pm 0.05^{a} \\
-0.03 \pm 0.26\end{array}$ & $\begin{array}{l}0.81 \pm 0.01^{\mathrm{ab}} \\
-0.24 \pm 0.01\end{array}$ & $\begin{array}{l}0.88 \pm 0.04^{b} \\
-0.21 \pm 0.15\end{array}$ & \\
\hline 126 & $\begin{array}{l}\text { MW } \\
\text { SGR }\end{array}$ & & & & $\begin{array}{c}0.78 \pm 0.01 \\
-0.26 \pm 0.04\end{array}$ & & \\
\hline 140 & FW & & & & 0.73 & & \\
\hline
\end{tabular}

In the same line, different letters indicate statistical significant differences $(P<0.05)$ among the groups.

The mean weights of marbled crabs tended to reduce on different days (Figure 4). Groups of D and $0 \%$ did not live until the $14^{\text {th }}$ days. Mean weights showed a decrease for $5 \%$ on $42^{\text {nd }}$ day, for $25 \%$ and
$35 \%$ on the $56^{\text {th }}$ day and for $15 \%$ on the $70^{\text {th }}$ day. In addition, moults were observed on $27^{\text {th }}, 42^{\text {nd }}$ and $93^{\text {rd }}$ days (one individual for each day) in the $25 \%$ group. 


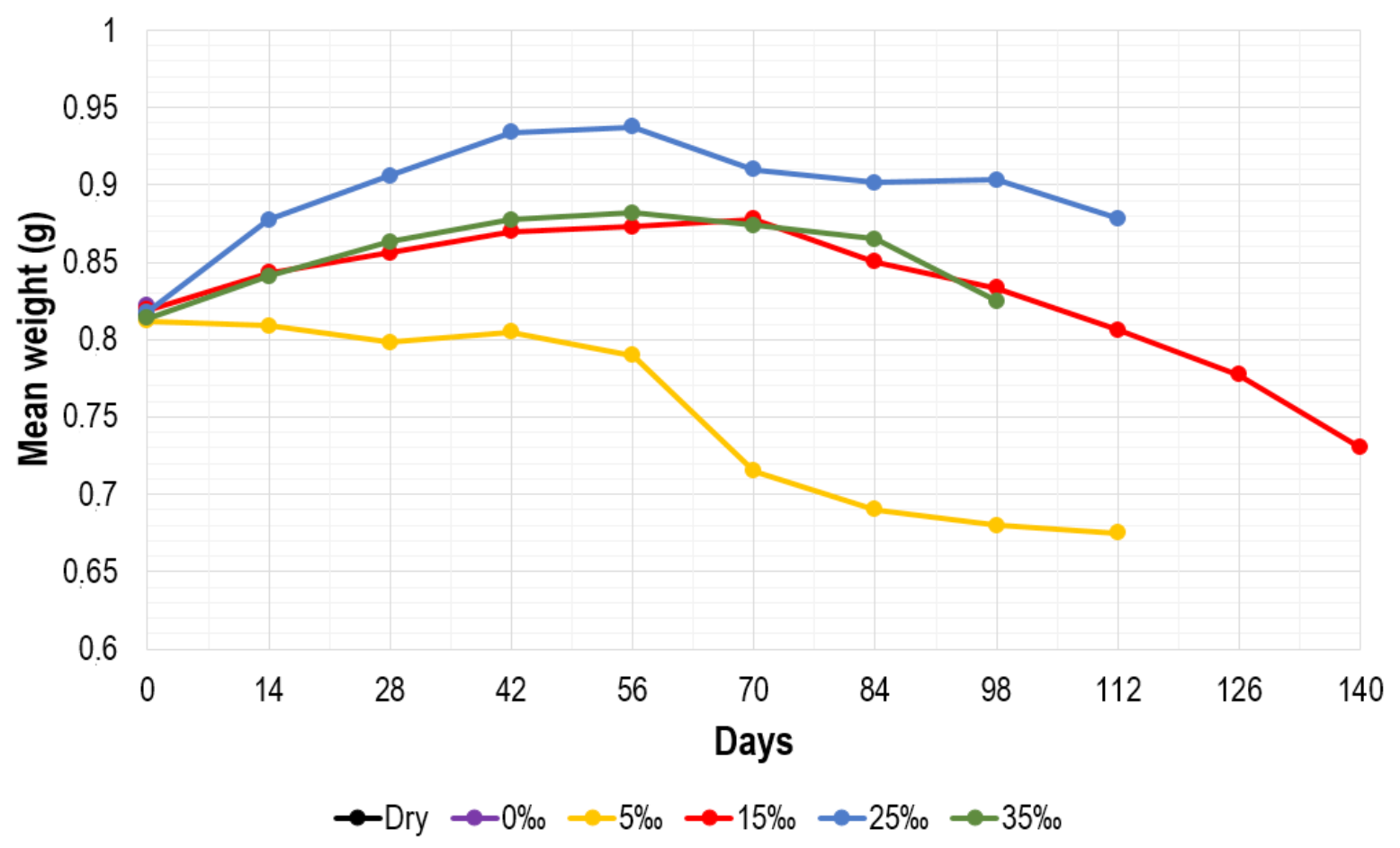

Figure 4. Changes of average body weights (g) of marbled crabs during 140 days experiment

The data of the carapace lengths $(\mathrm{CL})$ and carapace widths (CW) of the experimental groups were given in Table 2. The final mean carapace length (FMCL) and final mean carapace width (FMCW) of $25 \%$ o showed the highest value among all groups ( $P<0.05)$. FMCL of $15 \%$ was significantly higher than $D, 0 \%, 5 \%$ and $35 \%$ groups $(P<0.05)$. FMCW of $5 \%$ was significantly lower than $0 \%$, $15 \%$, $25 \%$ and $35 \%$ o groups $(P<0.05)$.

Table 2. Initial mean carapace lengths (IMCL, $\mathrm{mm}$ ), final mean carapace lengths ( $F M C L, m m$ ), initial mean carapace widths (IMCW, $\mathrm{mm}$ ) and final mean carapace widths (FMCW, $\mathrm{mm}$ ) of the starved marbled crabs in different salinity levels during 140-days

\begin{tabular}{lcccccc}
\hline & $\mathbf{D}$ & $\mathbf{0 \%}$ & $\mathbf{5 \%}$ & $\mathbf{1 5 \%}$ & $\mathbf{2 5 \%}$ & $\mathbf{3 5 \%}$ \\
\hline IMCL & $7.40 \pm 0.60$ & $7.45 \pm 0.60$ & $7.20 \pm 0.50$ & $7.65 \pm 0.33$ & $7.80 \pm 0.24$ & $7.55 \pm 0.33$ \\
FMCL & $7.65 \pm 0.76^{\mathrm{ab}}$ & $8.05 \pm 0.80^{\mathrm{b}}$ & $7.38 \pm 0.88^{\mathrm{a}}$ & $8.50 \pm 0.43^{\mathrm{c}}$ & $9.21 \pm 0.29^{\mathrm{d}}$ & $8.07 \pm 0.53^{\mathrm{b}}$ \\
IMCW & $8.00 \pm 0.68$ & $8.10 \pm 0.69$ & $7.85 \pm 0.61$ & $8.20 \pm 0.35$ & $8.35 \pm 0.27$ & $8.05 \pm 0.33$ \\
FMCW & $8.20 \pm 0.84^{\mathrm{ab}}$ & $8.70 \pm 0.86^{\mathrm{bc}}$ & $8.00 \pm 0.94^{\mathrm{a}}$ & $9.10 \pm 0.49^{\mathrm{c}}$ & $10.00 \pm 0.36^{\mathrm{d}}$ & $8.64 \pm 0.55^{\mathrm{bc}}$ \\
\hline
\end{tabular}

In the same line, different letters indicate statistical significant differences $(P<0.05)$ among the groups.

\section{DISCUSSION}

The present study showed that Pachygrapsus marmoratus individuals survived $2.0 \pm 0.5$ days at $17.6^{\circ} \mathrm{C}$ without water and food. Similarly, this species was lived 5 days at $20^{\circ} \mathrm{C}$ without water, and more than 1 week at $12^{\circ} \mathrm{C}$ (Pora, 1939; Vernet-Cornubert, 1958). Our results indicated that the highest survival time was determined as 140 days at $15 \%$ o salinity. Moreover, $25 \%$, 35\% and $5 \%$ salinity levels exhibited longer survival times than 0\%o. Similarly, Costlow (1967) noticed that eggs and larvae of blue crabs (Callinectes sapidus) exhibited higher survival rates in higher salinity levels.

Salinity also plays an important role in the development and growth of crab species (Fisher, 1999; Castejón et al., 2015). Intermolt duration of C. sapidus was affected by salinity (Cházaro-Olvera and Peterson, 2004). Furthermore, Long et al. (2017) investigated the impacts of salinity on the gonadal 
development of Chinese mitten crab (E. sinensis) and reported that gonadosomatic index (GSI) showed a significant increase at salinity levels of $12 \%$ and $18 \%$ with compared to lower salinities of $0 \%$ and $6 \%$. Fisher (1999) declared that there was a negative correlation between salinity and growth of $C$. sapidus. In the present study, the optimal salinity level for the restricted growth was determined as 25\%o. Crabs showed lower growth rate at the dry area and low salinity level (5\%o).

Nutritional stress affects various important parameters in crustaceans, such as growth performance, energy metabolism or nutrient deposition. The growth increased for a while in this study, even though the crabs were left hungry. Then, growth rates of all groups decreased to minus on $84^{\text {th }}$ day. Comoglio et al. (2008) reported the similar situation in southern king crab (Lithodes santolla) which survived at 12 days without feeding. This previous study has been pointed out that the minus growth rate observed on the $9^{\text {th }}$ day. In contrast, Wen et al. (2006) declared that continuous weight loss in $E$. sinensis for 70 days. Energy metabolism of crustaceans is difficult to put on a standard schedule (Oliveira et al., 2003). The metabolic activities of many crabs decreased during starvation and they consume protein, glycogen and lipid sources (Oliveira et al., 2004; Wen et al., 2006). Differences in the consumed organic material may determine the rise and fall in restricted growth. Furthermore, the mean weight of crabs which represented at 25\%o salinity level was moderately higher than all other groups during the study. This differentiation can be

\section{REFERENCES}

APPA. (2018). The 2017-2018 APPA National Pet Owners Survey Debut. http://americanpetproducts.org/Uploads/MemServices/ GPE2017_NPOS_Seminar.pdf (Access Date: 07.05.2018).

Arab, A., Kazanjian, G. \& Bariche, M. (2015). Biological traits suggest a niche overlap between two grapsid crabs sharing the rocky intertidal of the eastern Mediterranean. Journal of the Marine Biological Association of the United Kingdom, 95(8), 1685-1692. DOI: $10.1017 /$ S0025315415001010

Aydın, M., Karadurmuş, U. \& Tunca, E. (2014). Biological characteristics of Pachygrapsus marmoratus in the southern Black Sea (Turkey). Journal of the Marine Biological Association of the United Kingdom, 94(7), 1441-1449. DOI: 10.1017/S0025315414000253

Blaszkowski, C. \& Moreira, G.S. (1986). Combined effects of temperature and salinity on the survival and duration of larval stages of Pagurus criniticornis (Dana) (Crustacea, Paguridae). Journal of Experimental Marine Biology and Ecology, 103(1-3), 7786. DOI: 10.1016/0022-0981(86)90133-4 explained by molting in this group. Small increments were found in carapace lengths and carapace widths from initial to final measurements in this study. Some previous studies (Penha-Lopes et al., 2006; Figueiredo et al., 2008) related to the ornamental crab (M. forceps) were supported to results of this present study.

It should be noted that salinity influences the feeding behaviour of crabs. For instance, Shentu et al. (2015) reported that at the low salinity levels (e.g. 5\%o), crabs exhibited a decreased food intake. Little is known about the feeding of $P$. marmoratus in the aquariums or tanks. Cuesta and Rodríguez (2000) reported that the fifth zoeal stage of $P$. marmoratus cultured at $26^{\circ} \mathrm{C}$, Artemia sp. nauplii were used as a bait and it was reared in 24 days. $P$. marmoratus, is one of the most abundant intertidal crab species of the Mediterranean Basin (Flores and Paula, 2002a), which can be considered a potential aquarium animal due to the high population and its attractive colours of the body. Colour varies from violet brown to almost black with a marbled yellowishbrown pattern (Ingle, 1997).

In conclusion, this study suggests that dry area and low salinity levels (e.g. $0 \%$ and $5 \%$ o) result in the low survival rates in $P$. marmoratus. The optimal salinity levels were determined as $15 \%$ o for survival and $25 \%$ o for restricted growth.

\section{ACKNOWLEDGEMENTS}

We would like to thank the officers of the Republic of Turkey Ministry of Forestry and Water Affairs who provided the research permission for the fieldworks.

Bryars, S.R. \& Havenhand. J.N. (2006). Effects of constant and varying temperatures on the development of blue swimmer crab (Portunus pelagicus) larvae: laboratory observations and field predictions for temperate coastal waters. Journal of Experimental Marine Biology and Ecology, 329(2), 218-229. DOI: 10.1016/j.jembe.2005.09.004

Calado, R., Lin J., Rhyne, A.L., Araújo R. \& Narciso L. (2003a). Marine ornamental decapods - popular, pricey and poorly studied. Journal of Crustacean Biology, 23, 963-973. DOI: 10.1651/C-2409

Calado, R., Narciso, L., Morais, S., Rhyne, A. L. \& Lin, J. (2003b). A rearing system for the culture of ornamental decapod crustacean larvae. Aquaculture, 218(1-4), 329-339. DOI: $10.1016 /$ S0044-8486(02)00583-5

Calado, R., Vitorino, A., Dionísio, G. \& Dinis, M.T. (2007). A recirculated maturation system for marine ornamental decapods. Aquaculture, 263(1-4), 68-74. DOI: 10.1016/j.aquaculture.2006.10.013

Calado, R., Pimentel, T., Vitorino, A., Dionísio, G. \& Dinis, M.T. (2008). Technical improvements of a rearing system for the culture of decapod crustacean larvae, with emphasis on 
marine ornamental species. Aquaculture, 285(1-4), 264-269. DOI: 10.1016/j.aquaculture.2008.08.019

Cannicci, S., Paula, J. \& Vannini, M. (1999). Activity pattern and spatial strategy in Pachygrapsus marmoratus (Decapoda: Grapsidae) from Mediterranean and Atlantic shores. Marine Biology, 133, 429e435. DOI: 10.1007/s002270050481

Cannicci, S., Gomei, M., Boddi, B. \& Vannini, M. (2002). Feeding habits and natural diet of the intertidal crab Pachygrapsus marmoratus: opportunistic browser or selective feeder? Estuarine, Coastal and Shelf Science, 54(6), 983-1001. DOI: 10.1006/ecss.2001.0869

Cannicci, S., Gomei, M., Dahdouh-Guebas, F., Rorandelli, R. \& Terlizzi, A. (2007). Influence of seasonal food abundance and quality on the feeding habits of an opportunistic feeder, the intertidal crab Pachygrapsus marmoratus. Marine Biology, 151(4), 1331-1342. DOI: 10.1007/s00227-006-0570-3

Castejón, D., Ribes, E., Durfort, M., Rotllant, G. \& Guerao, G. (2015). Foregut morphology and ontogeny of the mud crab Dyspanopeus sayi (Smith, 1869) (Decapoda, Brachyura, Panopeidae). Arthropod Structure \& Development, 44(1), 33-41.

Cházaro-Olvera, S. \& Peterson, M.S. (2004). Effects of salinity on growth and molting of sympatric Callinectes spp. from Camaronera Lagoon, Veracruz, Mexico. Bulletin of Marine Science, 74(1), 115-127.

Comoglio, L., Goldsmit, J. \& Amin, O. (2008). Starvation effects on physiological parameters and biochemical composition of the hepatopancreas of the southern king crab Lithodes santolla (Molina, 1782). Revista de Biología Marina y Oceanografía, 43(2), 345-353.

Coquereau, L., Grall, J., Clavier, J., Jolivet, A. \& Chauvaud, L. (2016). Acoustic behaviours of large crustaceans in NE Atlantic coastal habitats. Aquatic Biology, 25, 151-163. DOI: 10.3354/ab00665

Costlow, J.D. (1967). The effect of salinity and temperature on survival and metamorphosis of megalops of the blue crab Callinectes sapidus. Helgoländer Wissenschaftliche Meeresuntersuchungen, 15(1), 84-97.

Cuesta, J.A. \& Rodríguez, A. (2000). Zoeal stages of the intertidal crab Pachygrapsus marmoratus (Fabricius, 1787) (Brachyura, Grapsidae) reared in the laboratory. Hydrobiologia, 436(1-3), 119 130. DOI: 10.1023/A:1026576614590

Dauvin, J.C. (2012). Establishment of a population of marbled crab Pachygrapsus marmoratus (Crustacea: Brachyura: Grapsoidea) on the coast of northern Cotentin, Normandy, on the western English Channel. Marine Biodiversity Records, 5, e56. DOI: $10.1017 /$ S1755267212000334

Deli, T., Bahles, H., Said, K. \& Chatti, N. (2015). Patterns of genetic and morphometric diversity in the marbled crab (Pachygrapsus marmoratus, Brachyura, Grapsidae) populations across the Tunisian coast. Acta Oceanologica Sinica, 34(6), 49-58.

\section{DOI: 10.1007/s13131-015-0687-7}

Figueiredo, J., Penha-Lopes, G., Narciso, L. \& Lin, J. (2008). Effect of starvation during late megalopa stage of Mithraculus forceps (Brachyura: Majidae) on larval duration, synchronism of metamorphosis, survival to juvenile, and newly metamorphosed juvenile size. Aquaculture, 274(1), 175-180. DOI: 10.1016/j.aquaculture.2007.10.052

Fisher, M.R. (1999). Effect of temperature and salinity on size at maturity of female blue crabs. Transactions of the American Fisheries Society, 128(3), 499-506. DOI: 10.1577/15488659(1999) $128<0499$ :EOTASO> 2.0.CO;2

Flores, A.A. \& Paula, J. (2002a). Population dynamics of the shore crab Pachygrapsus marmoratus (Brachyura: Grapsidae) in the central Portuguese coast. Journal of the Marine Biological Association of the United Kingdom, 82(2), 229-241. DOI: $10.1017 /$ S0025315402005404

Flores, A.A. \& Paula, J. (2002b). Sexual maturity, larval release and reproductive output of two brachyuran crabs from a rocky intertidal area in central Portugal. Invertebrate Reproduction \& Development, 42(1),21-34.DOI: 10.1080/07924259.2002.9652506

Gardner, C. \& Maguire, G.B. (1998). Effect of photoperiod and light intensity on survival, development and cannibalism of larvae of the Australian giant crab Pseudocarcinus gigas (Lamarck). Aquaculture, 165(1-2), 51-63. DOI: 10.1016/S00448486(98)00245-2

Hamasaki, K. (2003). Effects of temperature on the egg incubation period, survival and developmental period of larvae of the mud crab Scylla serrata (Forskål) (Brachyura: Portunidae) reared in the laboratory. Aquaculture, 219(1-4), 561-572. DOI: 10.1016/S0044-8486(02)00662-2

Ingle, R. (1997). Crayfishes, Lobsters and Crabs of Europe - An Illustrated Guide to Common and Traded Species. Springer Netherlands, 281 p. DOI: 10.1007/978-94-011-5872-5

Karadal, O. \& Öndes, F. (2018). Potential use of crab species in Turkey for the marine aquariums. Ecology 2018 International Symposium, 19-23 June 2018, Kastamonu, Turkey, pp. 751.

Kisling, V.N. (2000). Zoo and Aquarium History: Ancient Animal Collections to Zoological Gardens. CRC Press, WTA Boca Raton, Florida, USA, $440 \mathrm{p}$.

Long, X., Wu, X., Zhao, L., Ye, H., Cheng, Y. \& Zeng, C. (2017). Effects of salinity on gonadal development, osmoregulation and metabolism of adult male Chinese mitten crab, Eriocheir sinensis. PLoS One, 12(6), e0179036. DOI: 10.1371/journal.pone.0179036

Madeira, D., Narciso, L., Cabral, H.N., Diniz, M.S. \& Vinagre, C. (2012). Thermal tolerance of the crab Pachygrapsus marmoratus: intraspecific differences at a physiological (CTMax) and molecular level (Hsp70). Cell Stress and Chaperones, 17(6), 707- 
716. DOI: $10.1007 / \mathrm{s} 12192-012-0345-3$

Nurdiani, R. \& Zeng, C. (2007). Effects of temperature and salinity on the survival and development of the mud crab Scylla serrata (Forsskal) larvae. Aquaculture Research, 38(14), 1529-1538. DOI: $10.1111 /$ j.1365-2109.2007.01810.x

Oliveira, G.T., Fernandes, F.A., Bond-Buckup, G., Bueno, A.A. \& Da Silva, R.S.M. (2003). Circadian and seasonal variations in the metabolism of carbohydrates in Aegla ligulata (Crustacea: Anomura: Aeglidae). Memoirs of Museum Victoria, 60(1), 59-62.

Oliveira, G.T., Rossi, I.C., Kucharski, L.C.R. \& Da Silva, R.S.M. (2004), Hepatopancreas gluconeogenesis and glycogen content during fasting in crabs previously maintained on a high-protein or carbohydrate-rich diet. Comparative Biochemistry and Physiology A: Molecular \& Integrative Physiology, 137(2), 383-390.

DOI: 10.1016/j.cbpb.2003.10.017

Paschke, K., Cumillaf, J.P., Loyola, S., Gebauer, P., Urbina, M., Chimal, M.E., Pascual, C. \& Rosas, C. (2010). Effect of dissolved oxygen level on respiratory metabolism, nutritional physiology, and immune condition of southern king crab Lithodes santolla (Molina, 1782) (Decapoda, Lithodidae). Marine Biology, 157(1), 7.

Paula, J., Nogueira Mendes, R., Mwalum, J., Raedig, C. \& Emmerson, W. (2003). Combined effects of temperature and salinity on larval development of the mangrove crab Parasesarma catenata Ortman, 1897 (Brachyura: Sesarmidae). Western Indian Ocean Journal of Marine Science, 2(1), 57-63. DOI: 10.4314/wiojms.v2i1.28429

Penha-Lopes, G., Rhyne, A.L., Lin, J. \& Narciso, L. (2005). The larval rearing of the marine ornamental crab, Mithraculus forceps (A. Milne Edwards, 1875) (Decapoda: Brachyura: Majidae). Aquaculture Research, 36(13), 1313-1321. DOI: 10.1111/j.1365-2109.2005.01349.x

Penha-Lopes, G., Rhyne, A. L., Lin, J. \& Narciso, L. (2006). Effects of temperature, stocking density and diet on the growth and survival of juvenile Mithraculus forceps (A. Milne Edwards, 1875) (Decapoda: Brachyura: Majidae). Aquaculture Research, 37(4), 398-408. DOI: 10.1111/j.1365-2109.2006.01447.x

Pora, E.A. (1939). Sur le comportement des Crustaces brachyoures de la Mer Noire aux variations de salinite du milieu ambiant. Annales Scientifiques de I'Université de Jassy, 25, 1-34.

Protopapas, N., Katsanevakis, S., Thessalou-Legaki, M. \& Verriopoulos, G. (2007). Relative growth of the semi-terrestrial crab Pachygrapsus marmoratus: an information-theory approach. Scientia Marina, 71(2), 383-394.

Redzuari, A., Azra, M.N., Abol-Munafi, A.B., Aizam, Z.A., Hii, Y.S. \& Ikhwanuddin, M. (2012). Effects of feeding regimes on survival, development and growth of blue swimming crab, Portunus pelagicus (Linnaeus, 1758) larvae. World Applied Sciences Journal, 18(4), 472-478. DOI: 10.5829/idosi.wasj.2012.18.04.313

Rodríguez, A. (1997). Larval and postlarval development of Pisa tetraodon (Pennant, 1777) (Decapoda: Majidae) reared in the laboratory. Journal of Plankton Research, 19(1), 29-41. DOI: 10.1093/plankt/19.1.29

Rodríguez, A. \& Jones, D.A. (1993). Larval development of Uca tangeri (Eydoux, 1835) (Decapoda: Ocypodidae) reared in the laboratory. Journal of Crustacean Biology, 13(2), 309-321. DOI: 10.1163/193724093X00093

Romano, N. \& Zeng, C. (2006). The effects of salinity on the survival, growth and haemolymph osmolality of early juvenile blue swimmer crabs, Portunus pelagicus. Aquaculture, 260(1-4), 151162. DOI: $10.1016 /$ j.aquaculture.2006.06.019

Ruscoe, I.M., Williams, G.R. \& Shelley, C.C. (2004). Limiting the use of rotifers to the first zoeal stage in mud crab (Scylla serrata Forskål) larval rearing. Aquaculture, 231(1-4), 517-527. DOI: 10.1016/j.aquaculture.2003.11.021

Sciberras, M. \& Schembri, P.J. (2008). Biology and interspecific interactions of the alien crab Percnon gibbesi in the Maltese Islands. Marine Biology Research, 4(5), 321-332.

DOI: $10.1080 / 17451000801964923$

Shentu, J., Xu, Y. \& Ding, Z. (2015). Effects of salinity on survival, feeding behavior and growth of the juvenile swimming crab, Portunus trituberculatus (Miers, 1876). Chinese Journal of Oceanology and Limnology, 33(3), 679-684. DOI: 10.1016/j.asd.2014.09.005

Silva, A.C.F., Brazão, S., Hawkins, S.J., Thompson, R.C. \& Boaventura, D. (2009). Abundance, population structure and claw morphology of the semi-terrestrial crab Pachygrapsus marmoratus (Fabricius, 1787) on shores of differing wave exposure. Marine Biology, 156(12), 2591-2599. DOI: 10.1007/s00227-009-1283-1

Stueckle, T.A., Shock, B. \& Foran, C.M. (2009). Multiple stressor effects of methoprene, permethrin, and salinity on limb regeneration and molting in the mud fiddler crab (Uca pugnax). Environmental Toxicology and Chemistry, 28(11), 2348-2359. DOI: 10.1007/s00343-015-4218-3

Sumer, C., Aksu, H., Celik, S. \& Bektas, S. (2016). Some biological characteristics of the marbled crab, Pachygrapsus marmoratus in the southern Black Sea (Sinop, Turkey). International Journal of Advances in Agricultural and Environmental Engineering, 3(2), 263265. DOI: 10.15242/IJAAEE.ER051602

Suprayudi, M.A., Takeuchi, T., Hamasaki, K. \& Hirokawa, J. (2002). Effect of Artemia feeding schedule and density on the survival and development of larval mud crab Scylla serrata. Fisheries Science, 68(6), 1295-1303. DOI: 10.1046/j.1444-2906.2002.00567.x

Türkmen, G., Bulguroğlu, S.Y. \& Aydoğan, G. (2011). Bring in some native osteichtyes marine fish species in Turkey to the marine aquarium (in Turkish with English abstract). Ege Journal of Fisheries and Aquatic Sciences, 28(3), 95-98.

Türkmen, G. \& Karadal, O. (2012a). The survey of the imported freshwater decapod species via the ornamental aquarium trade in Turkey. Journal of Animal and Veterinary Advances, 11(15), 2824-2827. DOI: 10.3923/javaa.2012.2824.2827 
Karadal, Ege Journal of Fisheries and Aquatic Sciences, 35(4), 407-416 (2018)

Türkmen, G. \& Karadal, O. (2012b). Effects of different aquarium feeds on growth and survival rate of red claw crab (Perisesarma bidens) (in Turkish with English abstract). Alinteri Journal of Agricultural Sciences, 23(2), 12-17.

Vernet-Cornubert, G. (1958). Recherches sur la sexualité du crabe Pachygrapsus marmoratus (Fabricius); Les Malacostracés des eaux souterraines. Archives de Zoologie Expérimentale et Générale, $96,101-276$

Vinagre, C., Madeira, D., Narciso, L., Cabral, H.N. \& Diniz, M.S. (2012). Effect of handling, confinement and crowding in HSP7O production in Pachygrapsus marmoratus, a model species for climate change experiments. Journal of Sea Research, 72, 64-68. DOI: 10.1016/j.seares.2012.05.013
Vitko, R. (2004). A history of the hobby. Reefkeeping Magazine, September 2004, 3(8), 01

Wen, X., Chen, L., Ku, Y. \& Zhou, K. (2006). Effect of feeding and lack of food on the growth, gross biochemical and fatty acid composition of juvenile crab, Eriocheir sinensis. Aquaculture, 252(2-4), 598-607. DOI: 10.1016/j.aquaculture.2005.07.027

Winch, J.J.W.W. \& Hodgson, A.N. (2007). The effect of temperature and salinity on oxygen consumption in the brachyuran crab Cyclograpsus punctatus (Crustacea: Decapoda: Grapsidae). African Zoology, 42(1), 118-123.

DOI: 10.3377/1562-7020(2007)42[118:TEOTAS]2.0.CO;2

Zar JH. (1999). Biostatistical Analysis. $4^{\text {th }}$ edt, Prentice-Hall Inc., Upper Saddle River, $929 \mathrm{p}$ 